\title{
Assessment of the relation of violence and burnout among physicians working in the emergency departments in Turkey
}

\author{
Bülent Erdur, M.D., ${ }^{1}$ Ahmet Ergin, M.D., ${ }^{2}$ Aykut Yüksel, M.D., ${ }^{5}$ \\ İbrahim Türkçüer, M.D., ${ }^{1}$ Cüneyt Ayrık, M.D., ${ }^{4}$ Bora Boz, M.D. ${ }^{3}$
}

\begin{abstract}
1'Department of Emergency Medicine, Pamukkale University Faculty of Medicine, Denizli ${ }^{2}$ Department of Public Health, Pamukkale University Faculty of Medicine, Denizli ${ }^{3}$ Department of Forensic Medicine, Pamukkale University Faculty of Medicine, Denizli ${ }^{4}$ Department of Emergency Medicine, Mersin University Faculty of Medicine, Denizli ${ }^{5}$ Department of Emergency Service, Göztepe Training and Research Hospital, İstanbul
\end{abstract}

\begin{abstract}
BACKGROUND: Violence and burnout are frequently seen among medical doctors; however, the relation is not clear. This study aimed to assess the violence and its possible effects on burnout in physicians working in emergency units.

METHODS: This cross-sectional study targeted all physicians working in the emergency units of Pamukkale University Hospital, County and City Hospitals, II 2 Emergency Services, and Private Hospitals in Denizli. Data were obtained by means of a self-administered questionnaire that consisted of questions on the demographics of the participants, Turkish version of the Maslach Burnout Inventory, and of the perpetrators of violence. What was also documented on the questionnaire was whether participants had been subjected to or had witnessed any verbal or physical violence during the previous one month of emergency physicians' certification program.
\end{abstract}

RESULTS: A total of one hundred and seventy-four physicians were included into the study (85\% of the targeted group). Many of the participants were between 24 and 59 years of age, with a mean age of $36.8 \pm 5.8$ years. Married male doctors working in the City Hospital made up the majority. There were significant associations between emotional exhaustion and total violence $(p=0.012)$ and verbal violence $(p=0.016)$; depersonalization and total violence $(p=0.02 I)$ and verbal violence $(p=0.012)$.

CONCLUSION: The results presented here indicated that there was a strong relation between burnout and violence experienced by physicians working in emergency units. Violence in the emergency department has a substantial effect on the physicians' well-being.

Key words: Burnout; emergency department; emergency physician, emergency physician wellness; violence.

\section{INTRODUCTION}

Burnout in emergency physicians is multi-factorial and has previously been linked to a number of factors related to the working environment. It may result from the progressive loss of the health care workers' ability to feel emotionally involved in their work. Continuous exposure to critical incidents may

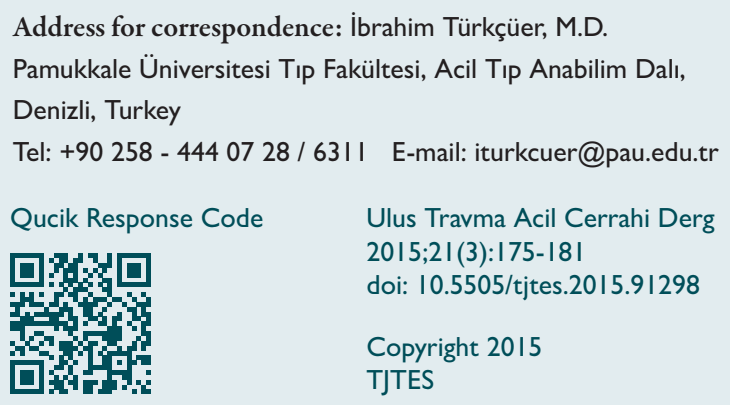

be another factor increasing the risk of developing professional burnout. Exposure to violent patients is an aspect of one of the many occupational hazards associated with working in an emergency department (ED), which may induce the development of burnout. ${ }^{[I]}$

Workplace violence is defined as any incident that puts health care workers at risk, which includes verbal abuse, threatening behaviour, or assault by a patient or patient accompanier, and it has currently been an increasing concern in the workplace. [2,3] Violence towards health care workers has been shown to often have short and long-term psychological effects on its victims, including post-traumatic stress disorder even when physical injury is not present. ${ }^{[4,5]}$ Healthcare workers bearing the brunt of violence can evaluate their work with patients in a negative light, which may lead to burnout. Eventually, they may develop cynical attitudes towards the patients, thereby, compromising the quality of care that they provide. 
In the hospital setting, emergency departments are common sites for substantial and significant violence. ${ }^{[6-8]}$ An increased risk of experiencing burnout has previously been linked to a number of factors related to the working environment of the emergency physicians. ${ }^{[1,9-12]}$ Certain environmental factors also appear to affect the risk of violence, and these factors are important variables for burnout. ${ }^{[13-15]}$ The problem of workplace violence and burnout in the EDs has not been well documented, researched, or managed. ${ }^{[16]}$ Additionally, the majority of the studies regarding these issues prior to the current study had been conducted in different populations, including emergency room nurses and other emergency staff. The purpose of this study was to assess the experience of workplace violence and the status of burnout in attending emergency physicians (EP) within the Emergency Medical System in a western Turkish city and detect the relation between these two.

\section{MATERIALS AND METHODS}

\section{Study Design and Subjects}

This cross sectional study included all physicians working in the emergency departments in Pamukkale University Hospital, State Hospitals, County Hospitals, Citywide Primary Health Care Centres, II 2 Emergency Services, and Private Hospitals in Denizli. One hundred and seventy-four physicians ( $85 \%$ of the targeted group) participated in the study. Denizli is located in the Aegean region of Turkey, which is a relatively developed part of Turkey and the population of the province is close to a million. Most physicians were government employees. The salaries of emergency room doctors in Turkey are low compared to those of the doctors in the Organization for Economic Co-operation and Development countries (OECD).

\section{Data Collection}

Data were obtained by means of a self-administered questionnaire that consisted of questions on the demographics of the participants, the Turkish version of the Maslach Burnout Inventory $(\mathrm{MBI}),{ }^{[17]}$ and the questions about whether participants had been subjected to or had witnessed any verbal or physical violence ${ }^{[18]}$ during the previous month were also included into the questionnaire. Data were collected during an emergency physician certification program. Content validity of the violence questions is supported by the literature. This questionnaire was piloted on a pre-study group of five people, and amendments were made to the document in accordance with this input.

$\mathrm{MBI}$ is the most widely used standardized measure of burnout, consisting 22 items with each of the three components of burnout (exhaustion, cynicism, professional efficacy) measured on separate likert-type subscales. It has been translated into Turkish and shown to have internal consistency: testretest reliability, convergent validity, and discriminant validity. [17] $\mathrm{MBI}$ evaluates three domains of burnout: (i) Emotional exhaustion, consisting of nine items measuring reduced energy and job enthusiasm, emotional and cognitive distancing from the job;

(ii) Depersonalization, consisting of five items measuring cynicism, lack of engagement and distancing from the patients, treatment of patients as inanimate, unfeeling objects; and

(iii) Personal accomplishment, consisting of eight items measuring perception of having an influence on others, working well with others and dealing well with problems. ${ }^{[19]}$

Each item consists of a 5-point rating scale ranging from I (never) to 5 (every day), and on the basis of the $\mathrm{MBI}$ responses, independent subscale scores are calculated for each of the three domains of burnout. High scores on emotional exhaustion or depersonalization subscales indicate burnout as do low scores on the personal accomplishment subscale.

\section{Data Entry and Analysis}

Data entry and analysis were performed using the SPSS-PC version 17.0 statistical package (SPSS; Cary, NC). Percentages, mean and SD were used as descriptive statistics. Student's t-test, Chi-square test, and ANOVA were used for bivariate analyses. Linear regression was the method of choice to adjust confounding variables.

\section{RESULTS}

One hundred and seventy-four doctors were included into the study. Table I shows the characteristics of the participants and association of burnout with socio-demographic and work-related factors in the EPs. Many of the participants were between 24 and 59 years of age. Married male doctors working in the State Hospital made up the majority. There were significant differences between the groups in marital status, workplace, hobbies, habits monthly income and work hours in terms of emotional exhaustion $(p=0.014$, $p=0.033, p<0.001, p=0.038, p=0.04$ and $p=0.006$, respectively); in terms of personal accomplishment in the workplace $(p<0.00 \mathrm{I})$ and in terms of depersonalization in hobbies $(p=0.024)$ (Table I).

There were significant differences between the groups in gender, workplace, hobbies in terms of verbal violence $(p=0.008$, $p=0.05$ and $p=0.002$, respectively) and in terms of total violence $(p=0.013, p=0.03$ and $p=0.002$, respectively) (Table 2).

There were significant associations between emotional exhaustion and total violence (the sum of verbal and physical violence) $(p=0.012)$ and verbal violence $(p=0.016)$; depersonalization and total violence (the sum of verbal and physical violence) $(p=0.021)$ and verbal violence $(p=0.012)$ experienced by physicians in the last month (Table 3 ). Table 4 shows the effects of factors on burnout. 
Table I. Description of the sample and association of burnout with demographic and work-related factors in EPs

\begin{tabular}{|c|c|c|c|c|c|c|c|}
\hline \multirow[b]{2}{*}{ Variables } & \multirow[t]{2}{*}{$\mathbf{n}$} & \multicolumn{2}{|c|}{ Emotional exhaustion } & \multicolumn{2}{|c|}{ Personal accomplishment } & \multicolumn{2}{|c|}{ Depersonalization } \\
\hline & & Mean $\pm S D$ & p* & Mean $\pm S D$ & p* & Mean $\pm S D$ & p* \\
\hline \multicolumn{8}{|l|}{ Age (years) } \\
\hline$<34$ & 60 & $24.0 \pm 5.9$ & 0.45 & $30.1 \pm 3.4$ & 0.69 & $10.6 \pm 3.5$ & 0.4 \\
\hline $35-44$ & 99 & $25.0 \pm 6.3$ & & $29.8 \pm 3.8$ & & $11.0 \pm 3.5$ & \\
\hline$\geq 45$ & 15 & $23.3 \pm 6.1$ & & $30.6 \pm 2.5$ & & $12.0 \pm 2.6$ & \\
\hline \multicolumn{8}{|l|}{ Sex } \\
\hline Male & 138 & $24.6 \pm 6.0$ & 0.69 & $30.0 \pm 3.4$ & 0.87 & $11.0 \pm 3.2$ & 0.61 \\
\hline Female & 36 & $24 . I \pm 6.7$ & & $29.9 \pm 3.9$ & & $10.7 \pm 4.1$ & \\
\hline \multicolumn{8}{|l|}{ Marital status } \\
\hline Married & 139 & $23.9 \pm 6.3$ & 0.014 & $30.1 \pm 3.7$ & 0.53 & $10.9 \pm 3.4$ & 0.93 \\
\hline Unmarried & 35 & $26.8 \pm 5.1$ & & $29.7 \pm 2.9$ & & $11.0 \pm 3.3$ & \\
\hline \multicolumn{8}{|l|}{ Having children } \\
\hline Yes & 129 & $25.3 \pm 5.5$ & 0.3 & $29.9 \pm 3.5$ & 0.96 & $10.6 \pm 3.3$ & 0.51 \\
\hline No & 45 & $24.2 \pm 6.4$ & & $30.0 \pm 3.6$ & & $11.0 \pm 3.4$ & \\
\hline \multicolumn{8}{|l|}{ Workplace } \\
\hline II2 emergency services & 49 & $22.6 \pm 6.0$ & 0.033 & $31.3 \pm 2.9$ & 0.001 & $10.7 \pm 3.4$ & 0.19 \\
\hline State hospital & 102 & $25.2 \pm 6.1$ & & $29.3 \pm 3.6$ & & $\mid I . I \pm 3.4$ & \\
\hline University hospital & 15 & $23.9 \pm 6.7$ & & $31.4 \pm 3.5$ & & $9.6 \pm 3.2$ & \\
\hline Other & 8 & $28.2 \pm 5.1$ & & $27.7 \pm 2.8$ & & $12.6 \pm 3.4$ & \\
\hline \multicolumn{8}{|l|}{ Work type } \\
\hline Shift & 17 & $23.2 \pm 5.4$ & $0.32^{* *}$ & $30.1 \pm 3.3$ & $0.99^{* *}$ & $10.4 \pm 3.6$ & $0.69^{\text {*th }}$ \\
\hline 24-h shift & 119 & $25.0 \pm 6.0$ & & $29.9 \pm 3.1$ & & $\mid I . I \pm 3.1$ & \\
\hline Day or night shift & 38 & $23.6 \pm 7.0$ & & $30.0 \pm 4.7$ & & $10.7 \pm 4.2$ & \\
\hline \multicolumn{8}{|l|}{ Hobbies } \\
\hline Yes & 118 & $23.4 \pm 6.2$ & $<0.001$ & $30.3 \pm 3.4$ & 0.085 & $10.5 \pm 3.3$ & 0.024 \\
\hline No & 56 & $26.9 \pm 5.5$ & & $29.3 \pm 3.8$ & & $11.8 \pm 3.5$ & \\
\hline \multicolumn{8}{|l|}{ Habits } \\
\hline None & 97 & $23.4 \pm 5.6$ & 0.04 & $30.2 \pm 3.4$ & 0.72 & $10.4 \pm 3.2$ & 0.03 \\
\hline Cigarette smoke & 46 & $25.6 \pm 6.9$ & & $29.5 \pm 3.4$ & & $11.0 \pm 3.9$ & \\
\hline Alcohol & 12 & $25.0 \pm 7.7$ & & $30.3 \pm 3.9$ & & $13.0 \pm 3.1$ & \\
\hline Both & 19 & $27.2 \pm 5.1$ & & $29.9 \pm 4.6$ & & $12.1 \pm 2.8$ & \\
\hline \multicolumn{8}{|l|}{ Working years in Medicine } \\
\hline $0-5$ & 20 & $24.9 \pm 5.4$ & 0.51 & $31.1 \pm 3.6$ & 0.38 & $10.4 \pm 2.9$ & 0.37 \\
\hline $6-10$ & 49 & $23.5 \pm 6.2$ & & $29.4 \pm 3.2$ & & $10.4 \pm 3.7$ & \\
\hline $11-15$ & 63 & $25.3 \pm 6.8$ & & $30.0 \pm 3.7$ & & $11.5 \pm 3.7$ & \\
\hline$>16$ & 42 & $24.4 \pm 5.5$ & & $30.0 \pm 3.6$ & & $11.0 \pm 2.9$ & \\
\hline \multicolumn{8}{|l|}{ Years in EM } \\
\hline$<5$ & 90 & $23.8 \pm 6.2$ & 0.23 & $30.2 \pm 3.4$ & 0.27 & $10.5 \pm 3.2$ & 0.19 \\
\hline $6-10$ & 49 & $25.5 \pm 5.8$ & & $29.3 \pm 3.5$ & & $11.3 \pm 3.3$ & \\
\hline$>11$ & 35 & $25.0 \pm 6.6$ & & $30.4 \pm 4.0$ & & $11.6 \pm 4.0$ & \\
\hline \multicolumn{8}{|l|}{ Predicted future in EM } \\
\hline$<5$ & 35 & $26.0 \pm 5.4$ & 0.16 & $30.2 \pm 2.8$ & 0.1 & $11.4 \pm 3.8$ & 0.11 \\
\hline $5-10$ & 57 & $24.8 \pm 6.3$ & & $29.1 \pm 4.0$ & & $11.5 \pm 3.2$ & \\
\hline$>10$ & 82 & $23.7 \pm 6.3$ & & $30.4 \pm 3.4$ & & $10.4 \pm 3.3$ & \\
\hline \multicolumn{8}{|l|}{ Monthly income } \\
\hline $2-3$ & 106 & $24.5 \pm 6.7$ & 0.03 & $29.9 \pm 3.6$ & 0.15 & $10.7 \pm 3.8$ & 0.6 \\
\hline $3-4$ & 46 & $25.3 \pm 5.3$ & & $29.4 \pm 3.5$ & & $11.5 \pm 2.8$ & \\
\hline $4-5$ & 13 & $25.5 \pm 4.0$ & & $31.2 \pm 2.9$ & & $11.0 \pm 2.0$ & \\
\hline$>5$ & 9 & $18.8 \pm 4.2$ & & $31.8 \pm 3.2$ & & $10.5 \pm 2.8$ & \\
\hline \multicolumn{8}{|l|}{ Work hours (per month) } \\
\hline$\leq 160$ & 36 & $22.0 \pm 6.2$ & 0.006 & $30.4 \pm 3.1$ & 0.37 & $\mid I .1 \pm 3.0$ & 0.8 \\
\hline$>160$ & 138 & $25.2 \pm 6.0$ & & $29.8 \pm 3.6$ & & $10.9 \pm 3.5$ & \\
\hline
\end{tabular}

*p values come from either t-test or Anova. **p values come from Kruskal Wallis. ED: Emergency department. 
Table 2. Description of the sample and association of violence with demographic and work-related factors in EPs

\begin{tabular}{|c|c|c|c|c|c|c|c|c|c|}
\hline \multirow[b]{2}{*}{ Variables } & \multicolumn{3}{|c|}{ Physical violence } & \multicolumn{3}{|c|}{ Verbal violence } & \multicolumn{3}{|c|}{ Total violence } \\
\hline & $\mathbf{n}$ & $\%$ & $\mathbf{p}$ & $\mathbf{n}$ & $\%$ & $\mathbf{p}$ & $\mathbf{n}$ & $\%$ & $\mathbf{p}$ \\
\hline \multicolumn{10}{|l|}{ Age (years) } \\
\hline$<34$ & 2 & 3.3 & 0.013 & 28 & 45.9 & 0.8 & 28 & 45.6 & 0.91 \\
\hline $35-44$ & 7 & 7.1 & & 41 & 41.4 & & 44 & 44.4 & \\
\hline$\geq 45$ & 0 & 0 & & 6 & 40.0 & & 6 & 40 & \\
\hline \multicolumn{10}{|l|}{ Sex n (\%) } \\
\hline Male & 9 & 6.5 & 0.24 & 52 & 37.7 & 0.008 & 55 & 39.9 & 0.013 \\
\hline Female & 0 & 0 & & 23 & 62.2 & & 23 & 62.2 & \\
\hline \multicolumn{10}{|l|}{ Marital Status } \\
\hline Married & 7 & 5 & 0.98 & 62 & 44.3 & 0.69 & 64 & 45.7 & 0.79 \\
\hline Unmarried & 2 & 6.1 & & 12 & 36.4 & & 13 & 39.4 & \\
\hline \multicolumn{10}{|l|}{ Having children } \\
\hline Yes & 2 & 4.3 & 0.80 & 18 & 39.1 & 0.55 & 19 & 41.3 & 0.36 \\
\hline No & 7 & 5.4 & & 57 & 44.2 & & 59 & 45.7 & \\
\hline \multicolumn{10}{|l|}{ Workplace } \\
\hline I 12 emergency services & 3 & 6.1 & 0.86 & 20 & 40.8 & 0.05 & 21 & 42.9 & 0.03 \\
\hline State hospital & 5 & 4.9 & & 50 & 49.0 & & 52 & 51.0 & \\
\hline University hospital & 0 & 0 & & 2 & 12.5 & & 2 & 12.5 & \\
\hline Other & 1 & 12.5 & & 3 & 37.5 & & 3 & 37.5 & \\
\hline \multicolumn{10}{|l|}{ Work type } \\
\hline Shift & 0 & 0 & 0.64 & 3 & 17.6 & 0.08 & 3 & 17.6 & 0.059 \\
\hline 24-h shift & 8 & 6.7 & & 54 & 45.0 & & 56 & 46.7 & \\
\hline Day or night shift & I & 2.6 & & 18 & 47.4 & & 19 & 50.0 & \\
\hline \multicolumn{10}{|l|}{ Hobbies } \\
\hline Yes & 5 & 4.2 & 0.25 & $4 I$ & 34.7 & 0.002 & 43 & 36.4 & 0.002 \\
\hline No & 4 & 7.0 & & 34 & 59.6 & & 35 & 61.4 & \\
\hline \multicolumn{10}{|l|}{ Habits } \\
\hline No & 5 & 5.6 & 0.67 & 39 & 43.3 & 0.1 & 40 & 44.4 & 0.15 \\
\hline Cigarette smoking & 2 & 4.3 & & 17 & 37 & & 18 & 39.1 & \\
\hline Alcohol & 2 & 16.7 & & 4 & 33.3 & & 5 & 41.7 & \\
\hline Both & 0 & 0 & & 8 & 42.1 & & 8 & 42.1 & \\
\hline \multicolumn{10}{|l|}{ Working years in Medicine } \\
\hline $0-5$ & 0 & 0 & 0.43 & 7 & 35 & 0.82 & 7 & 35.0 & 0.81 \\
\hline $6-10$ & 4 & 8 & & 21 & 42 & & 22 & 44.0 & \\
\hline $11-15$ & 4 & 6.3 & & 27 & 42.9 & & 29 & 46.0 & \\
\hline$>16$ & I & 2.4 & & 20 & 47.6 & & 20 & 47.6 & \\
\hline \multicolumn{10}{|l|}{ Years in medicine EM } \\
\hline$<5$ & 4 & 4.4 & 0.67 & 36 & 39.6 & 0.30 & 37 & 40.7 & 0.38 \\
\hline $6-10$ & 4 & 8.2 & & 20 & 40.8 & & 22 & 44.9 & \\
\hline$>11$ & I & 2.9 & & 19 & 54.3 & & 19 & 54.3 & \\
\hline \multicolumn{10}{|l|}{ Predicted future years in EM } \\
\hline$<5$ & I & 2.9 & 0.17 & 17 & 48.6 & 0.37 & 17 & 48.6 & 0.17 \\
\hline $5-10$ & 5 & 8.8 & & 27 & 47.4 & & 30 & 52.6 & \\
\hline$>10$ & 3 & 3.6 & & 31 & 37.3 & & 31 & 37.3 & \\
\hline \multicolumn{10}{|l|}{ Monthly income } \\
\hline $2-3$ & 6 & 5.6 & 0.64 & 44 & 41.1 & 0.58 & 62 & 57.9 & 0.42 \\
\hline $3-4$ & 3 & 6.5 & & 22 & 47.8 & & 22 & 47.8 & \\
\hline $4-5$ & 0 & 0 & & 4 & 30.8 & & 9 & 69.2 & \\
\hline$>5$ & 0 & 0 & & 5 & 55.6 & & 4 & 44.4 & \\
\hline \multicolumn{10}{|l|}{ Work hours (per month } \\
\hline$\leq 160$ & I & 2.8 & 0.67 & 12 & 33.3 & 0.19 & 12 & 33.3 & 0.09 \\
\hline$>160$ & 8 & 5.8 & & 63 & 45.3 & & 66 & 47.5 & \\
\hline
\end{tabular}


Table 3. Relation of violence with burnout in EPs

\begin{tabular}{|c|c|c|c|c|c|c|c|}
\hline \multirow[t]{2}{*}{ Variables } & \multirow[t]{2}{*}{$\mathbf{n}$} & \multicolumn{2}{|c|}{ Emotional exhaustion } & \multicolumn{2}{|c|}{ Personal accomplishment } & \multicolumn{2}{|c|}{ Depersonalization } \\
\hline & & Mean \pm SD & $\mathbf{p}$ & Mean \pm SD & $\mathbf{p}$ & Mean $\pm S D$ & $\mathbf{p}$ \\
\hline \multicolumn{8}{|c|}{ Total violence } \\
\hline Yes & 78 & $25.8 \pm 5.9$ & 0.012 & $29.4 \pm 3.8$ & 0.074 & $11.6 \pm 3.5$ & 0.021 \\
\hline No & 96 & $23.5 \pm 6.2$ & & $30.4 \pm 3.3$ & & $10.4 \pm 3.3$ & \\
\hline \multicolumn{8}{|c|}{ Physical violence } \\
\hline Yes & 9 & $26.8 \pm 3.7$ & 0.09 & $30.5 \pm 3.2$ & 0.63 & $11.3 \pm 3.4$ & 0.75 \\
\hline No & 165 & $24.4 \pm 6.3$ & & $29.9 \pm 3.6$ & & $10.9 \pm 3.4$ & \\
\hline \multicolumn{8}{|c|}{ Verbal violence } \\
\hline Yes & 75 & $25.8 \pm 6.0$ & 0.016 & $29.4 \pm 3.9$ & 0.1 & $11.7 \pm 3.5$ & 0.012 \\
\hline No & 99 & $23.5 \pm 6.2$ & & $30.3 \pm 3.2$ & & $10.4 \pm 3.3$ & \\
\hline
\end{tabular}

Table 4. Multivariate analysis of the effects of factors on burnout*

\begin{tabular}{|c|c|c|c|c|c|c|c|c|c|c|c|c|}
\hline \multirow[t]{2}{*}{ Variable } & \multicolumn{4}{|c|}{ Emotional exhaustion } & \multicolumn{4}{|c|}{ Personal accomplishment } & \multicolumn{4}{|c|}{ Depersonalization } \\
\hline & Beta & $\pm S E$ & $\mathbf{p}$ & $95 \% \mathrm{Cl}$ & Beta & $\pm S E$ & $\mathbf{p}$ & $95 \% \mathrm{Cl}$ & Beta & $\pm S E$ & $\mathbf{p}$ & $95 \% \mathrm{Cl}$ \\
\hline Total violence & 2.1 & 0.96 & 0.03 & $0.19-4.0$ & -0.94 & 0.6 & 0.1 & $-2.08-0.19$ & 1.09 & 0.5 & 0.049 & $0.004-2.2$ \\
\hline
\end{tabular}

\section{DISCUSSION}

This study showed that violence (especially, verbal violence) and burnout are common among physicians working in emergency departments. There have been few studies in the literature with similar results. ${ }^{[1,9,12,20-24]}$ Our results also indicated that there was a strong association between burnout and violence experienced by physicians working in emergency departments in our community. Violence-burnout relation in the literature has been referred to as anecdotal so far. However, this study is one of the few studies showing direct relation between violence and burnout.

All forms of aggression have the potential to impact significantly on the well-being of health professionals, including impaired job performance, moderate to severe and long-term psychological effects, burnout and turnover. ${ }^{[22,24-26]}$ The association between burnout and violence towards health care staff also found by Arnetz and Arnetz ${ }^{[20]}$ is similar to our study. It has also been reported that violence or threats experienced by health care staff, as well as burnout, have negative effects on the quality of health care services offered. ${ }^{[20,21]}$

There seems to be a tight circle between violence and burnout among physicians working in emergency departments. As long as violence is frequent, it is expected that it will have a substantial effect on the staff's well-being and burnout in our emergency departments. In another study within the EDs, the authors have experienced high levels of burnout primarily among physicians owing to the increased work load caused by access block and overcrowding, which, in turn, may lead to longer waiting times, and consequently, an increase in violence and aggression contributing to the risk of burnout. ${ }^{[23]}$ Violence is always present in the EDs, and the main contributing factors have been indicated as sudden illness or injury of individuals, overcrowding of the EDs because of access block or bed shortages, and longer waiting periods, alcohol or substance use. Misunderstandings about the assignments of medical priorities can easily aggravate patients and their companions, who are naturally in an anxious and worried mood. These findings are supported by other studies. ${ }^{[7,12,18,23]}$

The negative influence of violence on the well-being of the affected person has been demonstrated in some studies. The consequences are emotions like anger or anxiety extending to psychological disorders like burnout. ${ }^{[|2,27-3|]}$ Gascón et al. ${ }^{[30]}$ have found that there is a statistically significant association between verbal violence and anxiety and symptoms of PostTraumatic Stress Syndrome. In their report, both physical and non-physical violence has had an identical negative impact in terms of burnout, exhaustion and conflicts of values in health care workers, which are similar to our study. In addition, the same study has found that verbal and physical violence against accident and emergency service workers are shown to be simi- 
lar in the literature. In a recent study with a large participation, Estryn-Behar et al. ${ }^{[3]}$ have compared the rate of burnout and violence and found that both are higher in the ED physicians than in other physicians. Emergency physicians have declared being subjected to monthly violence from patients or their relatives twice as often as the physicians in the representative sample $(69.3 \%$ vs. $27.5 \%)$. They have reported that violence, as one of the working environment risk factors, is highly linked to burnout as was also demonstrated in our study.

The aggressions suffered by the workers fall within a wide range of risks that affect the safety and health of health workers, who are already subjected to high stress leading to high levels of burnout. Healthcare workers with burnout suffer from physical and emotional symptoms, lose joy in providing care, distance themselves from others, view their patients as objects, and spend less time with abusive patients. On the other hand, professional exhaustion of emergency doctors, with negative attitudes at work, increases the risk of aggressions against themselves and their colleagues.

\section{Limitations}

The main limitation of this study is due to its cross-sectional design. The study subjects were not followed-up, and the relation between violence and burnout was determined at the same time. The former one is always a subject to debate. The one-month brief period of the study, which has a potential to limit the sample size and reliability of the conclusion, seems to be another limitation. However, this should also be considered an advantage for this study in terms of reducing the recall bias and seeing the immediate effect of violence on burnout of the participants. However, it is thought that this did not cause a significant negative impact on the study results since it is known that the prevalence of violence is very high in our emergency rooms. It is a well-known fact from our daily practices and also from a previous study. ${ }^{[18]}$

\section{Conclusion}

The results presented here indicated that there was a strong association between burnout and violence (verbal or physical violence) experienced by physicians working in the emergency departments. Violence in the emergency department had a substantial effect on the well-being of the physicians.

Further studies on the topic are required. These studies should quantify the actual impact of violence and burnout on EP's well-being-time off, career change, and early retirement, and consider interventions/coping strategies to address the problem. Moreover, further studies could consider how ED activities, workforce numbers and crowded ED influences violence and burnout.

Funding: No funding received.

Conflict of interest: None declared.

\section{REFERENCES}

1. Crabbe JM, Bowley DM, Boffard KD, Alexander DA, Klein S. Are health professionals getting caught in the crossfire? The personal implications of caring for trauma victims. Emerg Med J 2004;21:568-72. CrossRef

2. Cole LL, Grubb PL, Sauter SL, Swanson NG, Lawless P. Psychosocial correlates of harassment, threats and fear of violence in the workplace. Scand J Work Environ Health 1997;23:450-7. CrossRef

3. Saines JC. Violence and aggression in A \& E: recommendations for action. Accid Emerg Nurs 1999;7:8-12. CrossRef

4. Caldwell MF. Incidence of PTSD among staff victims of patient violence. Hosp Community Psychiatry 1992;43:838-9. CrossRef

5. Wykes T, Whittington R. Reactions to assault. In T. Wykes (Ed.), Violence and health care professionals. London: Chapman \& Hall 1994. p. 105-26. CrossRef

6. Corbett SW, Grange JT, Thomas TL. Exposure of prehospital care providers to violence. Prehosp Emerg Care 1998;2:127-31. CrossRef

7. Grange JT, Corbett SW. Violence against emergency medical services personnel. Prehosp Emerg Care 2002;6:186-90. CrossRef

8. Mock EF, Wrenn KD, Wright SW, Eustis TC, Slovis CM. Prospective field study of violence in emergency medical services calls. Ann Emerg Med 1998;32:33-6. CrossRef

9. Goldberg R, Boss RW, Chan L, Goldberg J, Mallon WK, Moradzadeh $\mathrm{D}$, et al. Burnout and its correlates in emergency physicians: four years' experience with a wellness booth. Acad Emerg Med 1996;3:1156-64.

10. Felton JS. Burnout as a clinical entity--its importance in health care workers. Occup Med (Lond) 1998;48:237-50. CrossRef

11. Wallace JE, Lemaire JB, Ghali WA. Physician wellness: a missing quality indicator. Lancet 2009;374:1714-21. CrossRef

12. Gates DM, Ross CS, McQueen L. Violence against emergency department workers. J Emerg Med 2006;31:331-7. CrossRef

13. Gerberich SG, Church TR, McGovern PM, Hansen HE, Nachreiner NM, Geisser MS, et al. An epidemiological study of the magnitude and consequences of work related violence: the Minnesota Nurses' Study. Occup Environ Med 2004;61:495-503. CrossRef

14. Arnetz JE, Arnetz BB, Pettersson IL. Violence in the nursing profession: occupational and lifestyle risk factors in Swedish nurses. Work Stress 1996;10:119-27. CrossRef

15. Almberg B, Grafström M, Krichbaum K, Winblad B. The interplay of institution and family caregiving: relations between patient hassles, nursing home hassles and caregivers' burnout. Int J Geriatr Psychiatry 2000;15:931-9. CrossRef

16. Blanchard JC, Curtis KM. Violence in the emergency department. Emerg Med Clin North Am 1999;17:717-31. CrossRef

17. Ergin C. Adaptation and validity of MBI for measuring burnout among Turkish physicians and nurses. VIIth National Psychology Congress 1993; Ankara Turkish Psychologists Association.

18. Boz B, Acar K, Ergin A, Erdur B, Kurtulus A, Turkcuer I, et al. Violence toward health care workers in emergency departments in Denizli, Turkey. Adv Ther 2006;23:364-9. CrossRef

19. Maslach C, Jackson SE, Leiter MP. Maslach Burnout Inventory Manual, 3rd edition. Palo Alto, CA: Consulting Psychologists Press, 1996.

20. Arnetz JE, Arnetz BB. Violence towards health care staff and possible effects on the quality of patient care. Soc Sci Med 2001;52:417-27. CrossRef

21. Gates D, Fitzwater E, Succop P. Reducing assaults against nursing home caregivers. Nurs Res 2005;54:119-27. CrossRef

22. Fernandes CM, Bouthillette F, Raboud JM, Bullock L, Moore CF, Christenson JM, et al. Violence in the emergency department: a survey of 
health care workers. CMAJ 1999;161:1245-8.

23. Potter C. To what extent do nurses and physicians working within the emergency department experience burnout: A review of the literature. Aust Emerg Nurs J 2006;9:57-64. CrossRef

24. Lau JBC, Magarey J, McCutcheon H. Violence in the emergency department: A literature review. Aust Emerg Nurs J 2004;7:27-37. CrossRef

25. Pich J, Hazelton M, Sundin D, Kable A. Patient-related violence against emergency department nurses. Nurs Health Sci 2010;12:268-74. CrossRef

26. McGowan S, Wynaden D, Harding N, Yassine A, Parker J. Staff confidence in dealing with aggressive patients: a benchmarking exercise. Aust N Z J Ment Health Nurs 1999;8:104-8. CrossRef

27. Voyer P, Verreault R, Azizah GM, Desrosiers J, Champoux N, Bédard A. Prevalence of physical and verbal aggressive behaviours and associated factors among older adults in long-term care facilities. BMC Geriatr 2005;5:13. CrossRef
28. Evers W, Tomic W, Brouwers A. Aggressive behaviour and burnout among staff of homes for the elderly. Int J Ment Health Nurs 2002;11:29. CrossRef

29. Winstanley $\mathrm{S}$, Whittington $\mathrm{R}$. Violence in a general hospital: comparison of assailant and other assault-related factors on accident and emergency and inpatient wards. Acta Psychiatr Scand Suppl 2002;412:144-7. CrossRef

30. Gascón S, Martínez-Jarreta B, González-Andrade JF, Santed MA, Casalod Y, Rueda MA. Aggression towards health care workers in Spain: a multi-facility study to evaluate the distribution of growing violence among professionals, health facilities and departments. Int J Occup Environ Health 2009;15:29-35. CrossRef

31. Estryn-Behar M, Doppia MA, Guetarni K, Fry C, Machet G, Pelloux $\mathrm{P}$, et al. Emergency physicians accumulate more stress factors than other physicians-results from the French SESMAT study. Emerg Med J 2011;28:397-410. CrossRef

\section{ORIJIINAL ÇALIŞMA - ÖZET}

\section{Türkiye'de acil servislerde çalışan hekimler arasında şiddet} ve tükenmişlik ilişkisinin değerlendirilmesi

\section{Dr. Bülent Erdur, ${ }^{1}$ Dr. Ahmet Ergin, ${ }^{2}$ Dr. Aykut Yüksel, ${ }^{5}$ Dr. İbrahim Türkçüer, ${ }^{1}$ Dr. Cüneyt Ayrık, ${ }^{4}$ Dr. Bora Boz ${ }^{3}$}

${ }^{1}$ Pamukkale Üniversitesi Tıp Fakültesi, Acil Tıp Anabilim Dalı, Denizli

${ }^{2}$ Pamukkale Üniversitesi Tıp Fakültesi, Halk Sağlığı Anabilim Dalı, Denizli

${ }^{3}$ Pamukkale Üniversitesi Tıp Fakültesi, Adli Tıp Anabilim Dalı, Denizli

${ }^{4}$ Mersin Üniversitesi Tıp Fakültesi, Acil Tıp Anabilim Dalı, Mersin

${ }^{5}$ Göztepe Eğitim ve Araştırma Hastanesi, Acil Servisi, İstanbul

AMAÇ: Şiddet ve tükenmişlik hekimler arasında sık görülmektedir ancak ilişkileri açık değildir. Acil ünitelerinde çalışan hekimlerde şiddeti ve tükenmişlik üzerindeki muhtemel etkilerini değerlendirmeyi amaçladık.

GEREÇ VE YÖNTEM: Bu kesitsel çalışmaya Denizli Pamukkale Üniversitesi Hastanesi, il, ilçe hastaneleri, I I 2 Acil Servis ve özel hastanelerin acil birimlerde çalışan tüm hekimler alındı. Veriler, katılımcıların kendi kendilerine uyguladıkları Maslach Tükenmişlik Ölçeğinin Türkçe versiyonu, şiddetin failleri ve demografik bilgiler hakkındaki sorulardan oluşan bir anket vasıtasıyla elde edildi. Ayrıca katılımcıların acil hekimi sertifika programından önceki bir ay boyunca maruz kaldığı veya tanıklık ettiği herhangi bir sözlü ya da fiziksel şiddet ankette soruldu.

BULGULAR: Çalışmaya toplam 174 hekim (hedef grubun \%85) alındı. Katılımcıların çoğu 24 ve 59 yaş aralığında, ortalama yaş $36.8 \pm 5.8$ yıl idi. Şehir merkezindeki hastanede çalışanların çoğunluğunu evli erkek hekimler oluşturmaktaydı. Duygusal tükenme, toplam şiddet $(p=0.012)$ ve sözel şiddet $(p=0.016)$ arasında; duyarsızlaşma, toplam şiddet $(p=0.021)$ ve sözel şiddet $(p=0.012)$ arasında anlamlı bir ilişki vardı.

TARTIŞMA: Elde ettiğimiz sonuçlar, acil birimlerinde çalışan hekimlerin yaşadığı tükenmişlik ve şiddet arasında güçlü bir ilişkinin olduğunu göstermektedir. Acil servisteki şiddet, hekimlerin refahı üzerinde önemli bir etkiye sahiptir.

Anahtar sözcükler: Acil hekimi; acil hekimi sağıklı yaşam; acil tıp; şiddet; tükenmişlik.

Ulus Travma Acil Cerrahi Derg 2015;2I(3): 175-181 doi: 10.5505/tjtes.2015.91298 